Kinestetik : Jurnal Ilmiah Pendidikan Jasmani $5(1)(2021)$
Kinestetik : Jurnal Ilmiah Pendidikan Jasmani
https://ejournal.unib.ac.id/index.php/kinestetik/index
DOI : 10.33369/jk.v5i1.14608

\title{
INTERACTION OF TRAINING METHODS AND EXPLOSIVE POWER ON LEARNING OUTCOMES FOR RUNNING 100 METERS
}

\author{
Muhammad Ramli Buhari ${ }^{1 *}$, Muchamad Samsul Huda ${ }^{2}$, Hamdiana $^{3}$, Ruslan $^{4}$ \\ ${ }^{1234}$ Physical Education Study Program Faculty of Teacher Training and Education, Universitas \\ Mulawarman, Kalimantan Timur, Indonesia
}

\begin{tabular}{l} 
Article Info \\
\hline Article History : \\
Received : February 2021 \\
Revised : February 2021 \\
Accepted : March 2021 \\
Available online : March \\
2021
\end{tabular}

\section{Keywords:}

Acceleration, explosive power, Interaction, running sprinting

\begin{abstract}
The purpose of this study was to determine the interaction between the training method and the explosive power of the leg muscles on the learning outcomes of the 100 meter run. This research was conducted at the Teaching and Education Faculty of Mulawarman University with an experimental method, with a 2 x 2 factorial design. The sample in this study was 120 students, divided into 4 groups, each group consisting of 30 students. Analysis of the data used is a two-way Analysis of Variance (ANOVA). The results of the study stated that: (1) The acceleration sprint training method and the sprint training method did not have different effects on improving learning outcomes in running 100 meters, Fo $=5.452>$ Ft5\% db $(1 ; 116)=3.84$, (2) Without paying attention to the use of the two forms of training methods (acceleration sprint training method and the sprint training method), the explosive power of the strong leg muscles has a different effect when compared to the explosive power of the weak leg muscles on the learning outcomes of running 100 meters, Fo $=0.237 \leq \mathrm{Ft} 5 \% \mathrm{db}(1 ; 116)=3.84$, (3). There is an interaction between the training method and the explosive power of the leg muscles on the learning outcomes of the 100 meter run, Fo $=13.044>\mathrm{Ft} 5 \% \mathrm{db}(1 ; 116)=3.84$.
\end{abstract}

Corresponding address : Kuaro Street, Gunung Kelua Samarinda,

East Kalimantan, Indonesia

* email : ramlipjkr@gmail.com
ISSN 2685-6514 (Online)

ISSN 2477-331X (Print) 


\section{INTRODUCTION}

Running, jumping and throwing are the basic motion patterns that color most sports. The three basic movement patterns originate from the athletic sport, which is also called the parent of all sports. In short distance running, it requires the ability to supply energy which causes the limb to move quickly and maximally in carrying out movements with technical mastery of movements that are more complex than long distance running movements. The short distance running movement takes into account every step taken from the start until the body movement touches the finish line.

Short distance running according to (Henjilito et al., 2018) is all running numbers that are done at full speed or maximum speed along the distance that must be covered. Running the 100 meter sprint is an ability characterized by the process of rapidly moving the body from one place to another (Dwi et al., 2018). To produce a fast run, the things that need to be considered are: the posture of the body is leaning forward, the footsteps must be longer, the swing of the hand must be in accordance with the movement of the foot and the movement of the arm where the fingers are clenched or opened tight and relaxed. This is so that the maximum speed can be achieved until the finish line.

Physical preparation must be considered as a necessary element in training for the highest achievement. In an effort to improve the ability of students in the Physical Education Study Program, Faculty of Teacher Training and Education Mulawarman University has been given material for short distance running 100 meters, but the expected results have not been maximized. One of the reasons is the unavailability of the right form of training to improve learning outcomes for the 100 meter run. The initial identification found was the need to apply various speed training methods and know the initial physical abilities that support speed and improve the technical elements both separately and in combination, where the training process is the same from start to finish. According to (Bret et al., 2002) in (Stavridis et al., 2019) during sprint running, the lower limbs have to produce high forces in order to accelerate, and sustain high running speed. Meanwhile (Nur \& Hidayah, 2017) argues that physical training needs serious attention to be carefully planned and systematically so that the level of physical fitness and functional ability of the organs of the body is better.

Many factors determine the ability to run the sprint meter for a runner, including training programs, training methods, trainer abilities, athlete nutrition, facilities and infrastructure, physical abilities, interests and talents (Yulmardani, 2019). Common factors affecting success in physical education and sports are physical exercise. According to (Muhammadiah, 2015) physical exercise is training that aims to improve the ability of physical conditions because physical condition is the most important factor for every athlete in achieving peak performance and it takes a relatively long process and time to develop four important aspects, namely physical aspects, techniques, tactics and mentality if you want to achieve high sports achievements as high. Therefore, it is necessary to apply several training methods related to increasing the ability to move speed as measured by sprinting. In this study, the focus is on acceleration training methods and sprinting training methods.

An acceleration sprint is a run with a gradual increase in speed starting with jogging, striding and then sprinting 
between 45-110 meters in each section. In line with this, (Shaver, 1981) who is quoted (Hidayat, 2019) suggests that the type of accelerated sprint training is almost solely for developing speed and strength. This exercise includes jogging 45-100 meters, followed by brisk 45-100 meters, and finally a sprint 45-100 meter. Furthermore, recovering the origin, by walking, is done at a distance of 45-100 meters. Original recovery in accelerated sprinting is done by walking, because the original recovery between repetitions is almost complete. In training, the capacity of sprint is trained through repetitions of 30-40 meters starting from a standing start or from slow running. In this way, the improvement of the acceleration capacity is simultaneously stimulated. The first phase of the sprint is the most sensitive to the force, while after 20 meters the nervous component takes over (Raiola, 2014, Raiola 2012) in (Pisapia et al., 2019). During the repetitions on 3040 meters, the athlete must commit to the maximum without reservations. The length of the repetitions (30-40 meters) must not undergo significant changes, the number of repetitions and of series are, instead, influenced by the performance level and the characteristics of the athlete (Di Tore et al., 2016, Di Tore et al., 2018) in (Pisapia et al., 2019). Thus accelerated sprinting is a gradual change in speed from running slowly, running at a rather fast pace then running fast or running starting to slow and getting faster and faster.

According to (Fantri, 2019) accelaration sprint training can increase the speed of a runner in doing a short 100 meter run, because in its implementation runners move quickly and are required to be able to increase speed by not overriding the 100 meter running exercise itself. When viewed from the energy system used (Bafirman HB dan Asep Sujana Wahyuri, 2018) argue that the accelerated sprint training method develops $90 \%$ speed, 5\% an-aerobic endurance and power aerobic resistance by $5 \%$. The development of this speed is defined as the development of a combined energy system between the ATP-PC and the lactic acid system, the development of anaerobic resistance is defined as the development of a combined energy system between lactic acid and the aerobic system, and the development of aerobic endurance is defined as the development of an aerobic system. Phosphagen system can efficiently meet energy demands for maximally contracting muscle in an instantaneous manner, it's contributions are balanced by the rapid stimulation of the glycolytic metabolic pathway. Glycolytic metabolism, which functions fundamentally on glucose as a fuel source, is an added contributor to ATP turnover during explosive muscle action such as sprint running (Majumdar \& Robergs, 2011).

Sprint training is sprinting repeatedly over a distance of 40-50 meters at maximum speed interspersed with perfect breaks between repetitions. Speed training is a sprint specific training modality in which sprint training distances are often less than competition distance (eg, 30-, 60-, or 80-m dashes for 100-m sprinters) (Tsuka \& Awahara, 2016). The implementation of the sprint method activity in this study was started at the same place in each set of repetitions. The distance taken for a sprint as far as 60 meters starts from the starting line. After doing a sprint, continue with a loose step until the forward speed decreases and stops. The loose move is carried out within 20 meters then returns to the line to start the next set after reaching the required rest time range. Run fast and line up to the 60 meter line done with a standing start so as to develop and increase the speed to the maximum state. 
According to (Wibowo, 2019) an example of sprint training is running with a maximum speed covering a distance of 40 meters to 50 meters, with 16 to 20 repetitions. Each rep was given a complete recovery time (tr) and interval time (ti) (complete recovery). Comparison of recovery time (tr) 1:9, while for interval time (ti) 1:12-13, meaning that if the working time is 3 seconds, the recovery time given is around 30 seconds and the interval time is 36 seconds. This is in line with the opinion (Tsuka \& Awahara, 2016) the shorter sprinting distance compared with race distance permits sprinters to train with high intensity, as they can acutely run at a true maximal effort without the need to pace their horizontal sprinting velocity (hereafter, sprinting velocity).

When viewed from the energy system used (Bafirman HB dan Asep Sujana Wahyuri, 2018), it is argued that the sprint training method develops speed by $90 \%$, an-aerobic endurance by $6 \%$ and aerobic endurance by $4 \%$. The short execution time of the sprint section is to show maximum speed without causing fatigue. Long rest can be tolerated in order to keep recovering on the implementation of the next set.

In addition to these two training methods, the basic skills in dealing with physical elements possessed by each student are different. Therefore, one of the basic abilities that has a relationship with the training method to improve the learning outcomes of the 100 meter run in this study is to identify the initial ability of the leg muscle explosive power of the students.

Explosive power is the result of a combination of power and speed to perform maximum work in a very fast time. According to (Henjilito, 2017) strength here is defined as the ability of a muscle or group of muscles to cope with a load, both a burden in the sense of the body itself and a load in the sense of an object or tool that is moved by the body. Whereas speed shows how fast or slow the muscles contract to cope with the load. Thus the explosive power of the leg muscles is the ability of the leg muscles to carry out coordinated movements to carry out various activities, especially those using the legs. Muscle strength and speed of movement are the main characteristics of explosive ability.

Based on the above opinion, it can be stated that the training method (acceleration training and sprinting training) and the explosive power of the leg muscles are elements that are thought to be determining factors in sports performance, especially in sports that exert power quickly such as in 100 meter running.

\section{METHODS}

This study used an experimental method with a $2 \times 2$ factorial design. According to Sugiyono (2008:76) factorial design is a modification of the true experimental design, namely by paying attention to the possibility of a moderating variable affecting the treatment (independent variable) on the result (dependent variable). The independent variable manipulated in this study is the training method consisting of: (a) acceleration training method and (b) sprint training method. The independent variable that was controlled was the explosive power of the leg muscles, which consisted of (a) the explosive power of the leg muscles and (b) the explosive power of the leg muscles. While the dependent variable is the result of learning to run 100 meters, which is measured by running speed over a distance of 100 meters.

\section{Participants}

The research was conducted on students in the Physical Education Study 
Program, Faculty of Teacher Training and Education, Mulawarman University. A total of 228 people volunteered to participate in this study, especially students who program basic athletic courses and enrolled in odd semesters.

Exercises are carried out for two months with meetings three times a week. Focus on the readiness of students towards the achievement of learning outcomes for running 100 meters by providing appropriate training methods to increase running speed by paying attention to the explosive power factor of the leg muscles which is considered to be able to contribute significantly to increasing running speed. This is in line with what was stated by (Palmizal1, Nurkadri2, 2019) that training is a systematic way of working and functions as a tool with learning or training procedures to improve athlete achievement.

\section{Sampling Procedures}

Sampling was done using simple random sampling technique, which is to randomly assign a population of 228 students reached. Of the 228 students who have almost the same characteristics are determined to be the sample frame. The sample frame of 228 people was then drawn to be included in the two treatment groups, so that 114 people were obtained for the treatment group given the acceleration training method and 114 others for the sprint training method group. The next step in each group was a leg muscle explosive test for all members of the group. The test results of each group are arranged according to the score obtained from the highest score to the lowest score. After that, look for the average then determine the students who have high limb muscle explosive power and low leg muscle explosive power which is done by referring to the procedure proposed by Frank M.
Verducci, namely selecting $27 \%$ of the highest score data and $27 \%$ of the score lowest. $27 \%$ of the highest total data scores are classified in the group that has the ability to explosive leg muscles, while $27 \%$ of the lowest total scores (Dwi et al., 2018).

From this calculation, it was found that $27 \%$ of each group for the highest and lowest score was $27 \%$ x 114 $=30.78$ rounded to 30 people. So, each group numbered 30 people. The results of the sampling obtained were four groups, namely (1) the first group was a group of students who were given the acceleration training method who had the ability to explode leg muscles strong $\left(A_{1} B_{1}\right)$. The second group is a group of students who are given the sprint training method which is given to students who have the ability to explosive leg muscles are strong $\left(\begin{array}{ll}A_{2} & B_{1}\end{array}\right)$. The third group is a group of students who are given the acceleration training method with weak leg muscle explosive power $\left(\begin{array}{ll}A_{1} & B_{2}\end{array}\right)$. The fourth group was a group of students who were given the sprint training method with weak limb muscle explosive power (A2 $B_{2}$ ). Sample grouping can be seen in table 1 below:

Table 1. Sample Grouping Techniques

\begin{tabular}{cccc} 
method (A) & $\frac{\text { Training }}{\text { Acceleration }}$ & $\begin{array}{c}\text { Sprint } \\
\text { Sprint } \\
\text { training }\end{array}$ & Total \\
\cline { 1 - 1 } & $\begin{array}{c}\text { Training } \\
\text { (A1) }\end{array}$ & & \\
\cline { 1 - 3 } $\begin{array}{c}\text { Explosive muscle } \\
\text { ability (B) }\end{array}$ & & & \\
\hline Strong (B1) & 30 & 30 & 60 \\
\hline Weak (B2) & 30 & 30 & 60 \\
\hline
\end{tabular}

\section{Materials and apparatus}

The equipment and facilities used in the 100 meter running speed test include; A running track equipped with a start and finish line, a start flag, a stopwatch, a whistle, a test form, stationery and a camera. Implementation; 
Participants stand behind the start line, on the signal "ready" participants take a standing start, ready to run, then on the signal "Go" the participants run as fast as possible to the finish line. Time measurement is done from the time the start flag is raised until the runner crosses the finish line. The result recorded is the time it took the runner to cover the distance of 100 meters in units.

Equipment and facilities in the leg muscle explosive power test used include; Leg dynamometer, test form, stationary and camera. The implementation is tested standing on the footstool of the dynamometer leg without footwear, both hands holding the bottom of the dynamometer handle, the chain is arranged in such a way that the back position remains upright but the knees bend to make an angle of 102 degrees, immediately put the support belt around waist and gluteal muscles, the two ends of each attached to the end of the dynamometer handle stick. Perform the straightening motion of the upper and lower legs as hard as possible with a slow motion, but the position of the dynamometer grip stick should remain at shoulder level. Movement is considered a failure if the position of the dynamometer handle moves downward, the back is not upright, both hands participate in helping to pull the dynamometer handle upward and make movements. Each tested performs three tries and the highest value is taken.

\section{Procedures}

The research conducted on as many as 228 students who program basic athletic courses in the Physical Education Study Program, Faculty of Teacher Training and Education. They volunteered to participate in this study. The procedure is that in the first stage, an explosive power test is carried out to measure the explosive power of the high and low categories of students' limbs. The second stage is to do a pretest to run 100 meters to determine the speed of students before being given training treatment. Furthermore, after the pretest has been carried out, students are divided into four experimental groups, namely group one is a group of students who are given the acceleration training method that has the ability to explode leg muscles is strong. Group two is a group of students who are given the method fast running training which is given to students who have the ability to explode the strong leg muscles. Group three is a group of students who are given the acceleration training method which has weak limb muscle explosive power and group four is a group of students who are given the sprint training method which has weak limb muscle explosive power and the next stage is to do a posttest with a 100 meter running test to determine the effect of the training given. This experiment was conducted in the Kosetra field, Faculty of Teacher Training and Education University Mulawarman for two months with meetings three times a week.

\section{Design or Data Analysis}

The research design used is a $2 \mathrm{x}$ 2 factorial design. Described in a table 2, as below:

Table 2. Research design with randomized factorial design $2 \times 2$

\begin{tabular}{c|c|c|c}
\hline Training & $\begin{array}{c}\text { Acceleration } \\
\text { Sprint } \\
\text { Training } \\
\text { (A1) }\end{array}$ & $\begin{array}{c}\text { Sprint } \\
\text { Training } \\
\text { (A2) }\end{array}$ & Total \\
$\begin{array}{c}\text { Explosive muscle } \\
\text { ability (B) }\end{array}$ & & & \\
\hline Strong (B1) & A1B1 & A2B1 & A1 \\
\hline Weak (B2) & A1B2 & A2B2 & A2 \\
\hline
\end{tabular}

Data analysis is in accordance with the experimental research design by level $2 \times 2$, then hypothesis testing is carried out using two-way analysis of variance 
(ANOVA). However, before the analysis is carried out, several tests will be carried out first. First, raw data processing is carried out which aims to find the mean, median, mode, standard deviation, range, maximum value and minimum value. Furthermore, the frequency distribution is visualized through a table. Furthermore, the analysis requirements test was conducted, namely the normality test using the Liliefors, Sudjana (2002:466) test and the homogeneity test using the Bartlett Test (Sudjana, 2002:261) in this test it will be known whether the distribution of data from several variances is homogeneous (more than two variances), then testing the statistical hypothesis, namely analyzing the data using the analysis of variance (ANOVA) technique for experimental design design $2 \times 2$ factorial, with a significance level of $\alpha=0.05$.

\section{RESULT}

The data collected and processed are data obtained from 100 meter running test scores obtained by participants as a result of treatment for twenty-four meetings. The treatments applied are sprint training acceleration methods and sprint training methods: The results of learning to run 100 meters are recorded in units of time that are converted to values according to references published by the International Amateur Athletic Federation (IAAF). Then the price is $\mathrm{n}, \mathrm{x}$ and $\mathrm{s}$ for each treatment are summarized in table 2 below:

Table 3. Research results in training prints

\begin{tabular}{|c|c|c|c|}
\hline $\begin{array}{l}\text { Trai } \\
\text { ning Method (A) } \\
\text { Explosive } \\
\text { muscle ability (B) }\end{array}$ & $\begin{array}{c}\text { Acceleratio } \\
\mathbf{n} \\
\text { Sprinting } \\
\text { Training } \\
\text { (A1) }\end{array}$ & $\begin{array}{l}\text { Sprint } \\
\text { Traini } \\
\text { ng }\end{array}$ & $\begin{array}{c}\text { Gra } \\
\text { nd } \\
\text { mea } \\
\text { nea }\end{array}$ \\
\hline Strong (B1) & $\begin{array}{c}\text { I. } \bar{x}= \\
25,53 \\
n=30\end{array}$ & $\begin{array}{c}\text { III. } \overline{\mathrm{x}}= \\
19,69 \\
\mathrm{n}=30\end{array}$ & $\begin{array}{c}\bar{x}= \\
22,5 \\
8\end{array}$ \\
\hline
\end{tabular}

\begin{tabular}{c|c|c|c}
\hline Weak (B2) & II. $\overline{\mathrm{x}}=$ & IV. $\overline{\mathrm{x}}=$ & $\overline{\mathrm{x}}=$ \\
& 21,46 & 22,73 & 22,1 \\
& $\mathrm{n}=30$ & $\mathrm{n}=30$ & 0 \\
\hline & $\overline{\mathrm{x}}=23,50$ & $\overline{\mathrm{x}}=$ & $\overline{\mathrm{x}}=$ \\
& & 21,18 & 22,3 \\
& & & 4 \\
\hline
\end{tabular}

From the table above the results of the study noted that: there were mean differences between the four study groups. In A1 (sprint acceleration training method) $\overline{\mathrm{x}}=23,50>$ from A2 (sprint training method) $\bar{x}=21,18$, while for leg muscle blast ability (B) it can be seen that B1 (strong leg muscle burst ability) $\overline{\mathrm{x}}=$ $22,58>$ from B2 (weak leg muscle blast ability) $\overline{\mathrm{x}}=22,10$.

Furthermore, for simple effects, it can be seen that the average A1 $\overline{\mathrm{x}}=$ $25,53>$ from the $A 2 \bar{x}=19,69$ average for the treatment of B1. Mean A2 $\bar{x}=22,73>$ from the average A1 $\bar{x}=21,46$ for $B 2$ treatment. Means $\mathrm{B} 1 \overline{\mathrm{x}}=25,53>$ from average $\mathrm{B} 2 \overline{\mathrm{x}}=21,46$ for $\mathrm{A} 1$ treatment. Mean B2 $\bar{x}=22,73>$ from B1 $\bar{x}=19,69$ on average for $\mathrm{A} 2$ treatment.

The description above is only a description of the data obtained. To provide a more complete and precise interpretation, a more thorough analysis is still needed to test the hypothesis proposed using multifactorial variance analysis.

The results of the analysis of variants of the three main problems mentioned above are:

1. To verify whether or not there is a difference between the accelerated sprint training method and the sprint training method the results of learning to run 100 meters

2. To verify whether there is a difference between the explosive power of the strong leg muscles and the explosive power of the weak leg muscles on the learning outcomes of the 100 meter run

3. To verify whether or not there is an interaction between the leg muscle 
explosive power training method and the leg muscle explosive power capacity to the learning outcome of the 100 meter run.

The results of a summary analysis of the variance of the results of the three main problems in this study can be seen in Table 3 below:

Table 4. Data on the results of the analysis of variance of the study of

\begin{tabular}{l|r|r|r|r}
\hline S. Variant & \multicolumn{1}{|c|}{ JK } & DB & RJK & Fo \\
\hline Between A & 161.0083 & 1 & 161.0083 & 5.452 \\
\hline Between & 7.0083 & 1 & 7.0083 & 0.237 \\
\hline $\begin{array}{l}\text { Interaction } \\
\text { AB }\end{array}$ & 385.2083 & 1 & 385.2083 & 13.044 \\
\hline Within & 3425.7668 & 116 & 29.5324 & - \\
\hline Total & 3978.9917 & 119 & & - \\
\hline
\end{tabular}

Based on table 4 above, it can be stated as follows:

1. The testing of the first hypothesis shows that the accelerated sprint training method and the sprint training method do not have a different effect on the improvement of learning outcomes in running 100 meters, $\mathrm{F}_{\mathrm{o}}=$ $5.452>\mathrm{F}_{\mathrm{t}} 5 \% \mathrm{db}(1 ; 116)=3.84$.

2. Testing the second hypothesis shows that without paying attention to the use of the two forms of training methods, the explosive power of the strong leg muscles gives a different effect when compared to the explosive power of the weak leg muscles on the learning outcomes of running 100 meters, $\mathrm{F}_{\mathrm{o}}=$ $0.237 \leq \mathrm{F}_{\mathrm{t}} 5 \% \mathrm{db}(1 ; 116)=3.84$.

3 . Testing the third hypothesis shows that there is an interaction between the training method of increasing learning outcomes in running 100 meters with the ability of leg muscle explosive power, $\mathrm{F}_{\mathrm{o}}=13.044>\mathrm{F}_{\mathrm{t}} 5 \% \mathrm{db}(1 ; 116)$ $=3.84$.

\section{DISCUSSION}

The results of testing the first hypothesis stated that the acceleration sprint training method and the sprint training method did not have different effects on improving learning outcomes in running 100 meters, $\mathrm{F}_{\mathrm{o}}=5.452>\mathrm{F}_{\mathrm{t}} 5 \%$ $\mathrm{db}(1 ; 116)=3.84$. It states that both methods have the same effect to be used in increased running speed of 100 meters. There was an increase in running speed in both groups of acceleration running exercises and fast running exercises due to the constant running intensity at each repetition. Maintaining the running speed constantly will be better in increasing the stride length and stride frequency, as well as the development of fast twitch (FT) muscle fibers, to support the speed of running. FT fibers will be more stimulated so that it can cause enlargement of the size of muscle fibers followed by an increase in contractile filament proteins needed to produce greater strength. Changes in the FT fibers also cause high content of mitochondria and myoglobin to support oxidative aspects and both are very useful in providing the energy needed during physical activity. According to (Majumdar \& Robergs, 2011). The dominant metabolic energy system is the phosphagen system that relies heavily on the muscle store of creatine phosphate (PCr). In the phosphagen system, creatine kinase breaks down creatine phosphate into a creatine molecule and transfers inorganic phosphate (Pi) from $\mathrm{PCr}$ to ADP to form ATP. Thus, while the phosphagen system is at work (as long as creatine phosphate remains available) ATP is regenerated at a very high rate and muscle ATP is maintained at a moderately constant level.

This is in line with the results of research (Pisapia et al., 2019) in order to best compete a 100-meter race, it is 
necessary to improve one's general athletic level through a specific training program, which includes a strengthening of the cardiovascular system as well as endurance training. Likewise stated by (Majumdar \& Robergs, 2011) Performance in the $100 \mathrm{~m}$ sprint is influenced by a multitude of factors including starting strategy, stride length, stride frequency, physiological demands, biomechanics, neural influences, muscle composition, anthropometrics, and track and environmental conditions. Thus this condition is very supportive of an increase in leg muscle strength, running speed, leg muscle endurance, and cardiovascular endurance. Judging from the development of energy sources used at the time of the activity, the two training methods show significant differences.

The second hypothesis testing shows that without paying attention to the use of the two forms of training methods, the explosive power of the strong leg muscles has a different effect when compared to the explosive power of the weak leg muscles on the learning outcomes of running 100 meters, $\mathrm{F}_{\mathrm{o}}=$ $0.237 \leq \mathrm{F}_{\mathrm{t}} 5 \%$ db $(1 ; 116)=3.84$. Explosive power is a combination of leg muscle strength and contraction speed to produce the ability to move / change body position in the desired state. The explosive power of the leg muscles is the ability of the leg muscles to carry out coordinated movements to carry out various activities, especially those using the legs. Researchers believe that muscle fiber composition is genetically determined and minimally affected by training. Muscle strength and speed of movement are the main characteristics of explosive ability. For this reason, (Henjilito, 2017) training a short distance runner is not only given sprint speed training, but also requires training on all other components of physical conditions such as speed strength training, reaction speed and speed endurance training.

The findings from the results of this study provide clear evidence that the explosive power of the leg muscles will result in the ability to move or change the position of the body to another place in a faster time and this is needed when running a distance of 100 meters, while considering the results of the study (Souhaiel \& Denis, 2001) muscle power is a greater contributor during the accelerative phase of therace, while muscular resilience, the efficiency of the muscles to rebound, is inherent to top speed running.

The testing of the third hypothesis shows that there is an interaction between the training method and the explosive power of the leg muscles on the learning outcomes of the 100 meter run, $F_{o}=$ $13.044>\mathrm{Ft}_{\mathrm{t}} 5 \% \mathrm{db}(1 ; 116)=3.84$. This shows that variations in training methods will give different results if the ability of leg muscle explosive power (strong and weak) is a factor that is taken into account. In a set of repetition exercises in the method of acceleration of running exercises run longer when compared to a set of repetition exercises in the method of sprinting training. The length of the path taken in each set is done by exerting energy which mostly comes from the leg muscle group as the main limb. Especially in the sprint, leg muscle groups are required to be able to exert all of their ability to be able to move the body at the point needed in the shortest time possible. If the effort is related to the time element, the combination of both is the leg muscle explosive element. Sprint running, like most athletic activities, requires strength at fast velocities (power). (Majumdar \& Robergs, 2011) for example, individuals who have a genetic expression of fast-twitch muscle will be better suited to events that involve 
rapid and forceful muscle contractions such as sprinting.

Although not discussed in this article, sprint performance greatly depends on the health and motivation of the athlete. Injuries can considerably nearly performance, as canpoor mental focus. It is also important to recognize frequent ergogenic aid and supplementuse amongst athletes for performance enhancement. While such conduct is not encouraged or accepted by the greater athletics community, supplementation may be as much a factor in modern sprint performances as training programs that enhance technique.

\section{CONCLUSION}

The conclusions in this study are: (1) There is no difference in the effect of learning outcomes of running 100 meters between groups that are trained with the method of accelerating sprint training and groups that are trained with the method of sprint training. Without considering the abilities of the explosive power of the leg muscles of students who are strong and weak, the sprint training acceleration method does not have a better effect than the sprint training method. Thus both training methods have the same effect if applied without looking at the explosive characteristics of the leg muscles. (2) There was a difference in the effect between the ability of the explosive limbs on strong limbs and weak leg muscle explosive ability to learn to run 100 meters. Regardless of the form of exercise method used, the ability to blast leg muscles provides a better effect than the ability to blast weak leg muscles. (3) There is an interaction between the effect of the leg muscle explosive power training method with the leg muscle explosive power ability on the results of learning to run 100 meters.

\section{REFERENCES}

Bafirman HB dan Asep Sujana Wahyuri. (2018). Pembentukan Kondisi Fisik.

Dwi, D. R. A. S., Asmawi, M., Wasan, A., \& Widiastuti, W. (2018). Pengaruh Metode Latihan Dan Power Tungkai Terhadap Peningkatan Kecepatan Akselerasi Sprint. JUARA : Jurnal Olahraga, $\quad 3(2), \quad 62$. https://doi.org/10.33222/juara.v3i2.236

Fantri, Y. M. (2019). Pengaruh Latihan Acceleration Sprint Terhadap Prestasi Lari 100 Meter. 2(5), 1-3.

Henjilito, R. (2017). Pengaruh Daya Ledak Otot Tungkai, Kecepatan Reaksi dan Motivasi terhadap Kecepatan Lari Jarak Pendek 100 Meter pada Atlet PPLP Provinsi Riau. Journal Sport Area, 2(1), 70-78. https://doi.org/10.25299/sportarea.2017 .vol2(1).595

Henjilito, R., Asmawi, M., \& Tangkudung, J. (2018). the Influence of Exercise Method and Reactions Time To Skills Sprint 100 Meters. Jipes - Journal of Indonesian Physical Education and Sport, $\quad 4(1), \quad 126-140$. https://doi.org/10.21009/jipes.041.12

Hidayat, A. T. M. (2019). Peningkatan Kemampuan Lari Cepat Siswa Melalui Pendekatan Latihan Akeselrasi dan Hollow Sprint Kelas XI IPA SMA Negeri 1 Cipatat. Simpul Juara, 1(1), $1-8$.

http://sportasaintika.ppj.unp.ac.id/inde x.php/sporta/article/view/34

Majumdar, A., \& Robergs, R. (2011). The science of speed: Determinants of performance in the $100 \mathrm{~m}$ sprint: A response to Commentary. International Journal of Sports Science and Coaching, 6(3), 479-493. 
https://doi.org/10.1260/1747-

9541.6.3.479

Muhammadiah. (2015). Pengaruh Metode Latihan Lari Percepatan Dan Lari Interval Terhadap Keterampilan Bermain Sepakbola. 87-101.

Nur, M., \& Hidayah, T. (2017). Pengaruh Metode Latihan dan Power Otot Tungkai terhadap Kelincahan. Journal of Physical Education and Sports, 6(3), 279-285.

Palmizal1, Nurkadri2, B. A. P. (2019). Pengaruh Latihan Lompat Gawang Dan Latihan Lompat Samping Terhadap Kemampuan Heading Bola Pada Permainan Sepakbola Ditinjau Dari Daya Ledak Otot Tungkai. 11, 53-62.

Pisapia, F., Cassese, F. P., Valentini, M., \& D'isanto, T. (2019). Comparison between sprint training methods in different types of athletes. Journal of Human Sport and Exercise, 14(Proc4), S610-S617.

https://doi.org/10.14198/jhse.2019.14.P $\operatorname{roc} 4.19$

Stavridis, I., Smilios, I., Tsopanidou, A., Economou, T., \& Paradisis, G. (2019). Differences in the Force Velocity Mechanical Profile and the Effectiveness of Force Application During Sprint-Acceleration Between Sprinters and Hurdlers. Frontiers in Sports and Active Living, 1(September), 1-8. https://doi.org/10.3389/fspor.2019.000 26

Tsuka, M. I. O., \& Awahara, T. A. K. (2016). Acute Response Of Well-Trained Sprinters To A 100-M Race: Higher Sprinting Velocity Achieved With Increased Step Rate Compared With. 30(3), 635-642.
Wibowo, K. A. (2019). Pengaruh Speed Training Dan Interval Training Terhadap Speed Pada Pemain Sepakbola Ssb Universitas Negeri Semarang Tahun 2019.

Yulmardani, Y. (2019). Pengaruh Metode Latihan Acceleration Sprint terhadap Kemampuan Lari 60 Meter Siswa. JPGI (Jurnal Penelitian Guru Indonesia), $\quad 4(1), \quad 50$. https://doi.org/10.29210/02364jpgi000 5 